Apidologie, 1987, 18 (3), 243-252

\title{
IMPAIRMENT OF A CLASSICAL CONDITIONED RESPONSE OF THE HONEY BEE (APIS MELLIFERA L.) BY SUBLETHAL DOSES OF SYNTHETIC PYRETHROID INSECTICIDES
}

\author{
Kevin S. TAYLOR ${ }^{(1)}$, Gordon D. WALLER and Larry A. CROWDER ${ }^{(2)}$ \\ Agricultural Research Service, U.S. Department of Agriculture, \\ Carl Hayden Bee Research Center, 2000 E. Allen Road, \\ Tucson, Arizona 85719, U.S.A.
}

\begin{abstract}
SUMMARY
A classical conditioning experiment was used to compare the odor-mediated learned responses of honcy becs (Apis mellifera L.) previously exposed to one of 6 pyrethroid insecticides dissolved in acetone with the responses of bees exposed only to acetone. Untreated bees showed a relatively steep acquisition slope following training bouts 1-3, and then an asymptote in response of ca $90 \%$ positive responses following training bouts 4-7. Pyrethroid-treated bees learned at a slower rate but continued to show an improvement in positive responses throughout the test. However, treated bees attained only ca $60 \%$ positive responses after their seventh training bout. Odor training responses were least affected by fluvalinate and most scriously disrupted by flucythrinate and cyfluthrin; permethrin, fenvalerate, and cypermethrin were intermediate in their effect on the conditioned response.
\end{abstract}

\section{INTRODUCTION}

Determining mortality is a major way to evaluate the effects of insecticides on honey bees (Apis mellifera L.), but there is at present an increasing awareness of sublethal effects. Although pyrethroids are highly toxic to bees in laboratory tests (Stevenson et al., 1977 ; AtKins et al., 1981; SMART and StEvenson, 1982), when applied to crops they do not cause levels of mortality to foraging bees that result from other highly toxic insecticides owing to a paucity of foraging bees on the treated crop (Gerig, 1979; AtKINS, 1981 ; MoffetT et al., 1982 ; PIKE et al., 1982).

Relatively little research has been done with sublethal behavioral effects of insecticides on honey bees (and most other insects). The impact of a sublethal dose of parathion on the honey bee was studied by SCHRICKER and STEPHEN

(1) Present address : Pesticide Coordinator's Office. University of Arizona, Tueson AZ 85721.

(2) Present address : Department of Entomology, Oklahoma State University, Stillwater, OK 74078. 
(1970) and Schricker (1974 a, $1974 \mathrm{~b})$ who found interferences with the communication dances of bees. BRANDES (1984) also found parathion to alter honey bee dance patterns. Cox and WILson (1984) described abnormal behavior by permethrin-poisoned bees observed in a glass-walled observation hive.

Sublethal effects of permethrin have been observed in other insects. KAISSLING (1980) applied (+) trans-permethrin to olfactory hairs (sensilla trichodea) on antennae of male moths, Antheraea sp. or Bombyx mori, and recorded nerve impulses electrophysiologically that showed odor-induced bursts. KaISSLING postulated a breakdown of membrane potential from permethrin. Floyd and Crowder (1981) and Haynes and Baker (1985) found that the pink bollworm (PBW), Pectinophora gossypiella (Saunders), did not respond normally to the sex pheromone gossyplure after being exposed to permethrin. LINN and RoELOFs (1984) showed that male oriental fruit moths, Grapholitha molesta (Burk), treated with sublethal doses of permethrin had difficulty either orienting to a pheromone plume or initiating upwind flight in a flight tunnel.

Since other insects surviving sublethal doses of permethrin have been shown to have difficulty with odor perception and/or responses to pheromones, it seemed appropriate to test the conditioned responses to odors by honey bees that had survived sublethal doses of pyrethroid insecticides. Thus, we studied associative learning by honey bee survivors of $\mathrm{LC}_{50}$ levels of contact exposure (previously determined by us) to 6 selected pyrethroid insecticides.

\section{MATERIALS AND METHODS}

Using a Gary flight cone (GARY, 1967) approximately 20 foragers exiting from a colony were «funneled" into a 9-cm diameter glass petri dish (with a plastic top) containing an insecticide-treated filter paper. Before catching the bees, the paper $(9 \mathrm{~cm}$ diam) was placed in each glass petri dish and treated with $1.5 \mathrm{ml}$ of acetone, either with or without an $\mathrm{LC}_{50}$ dosage of 1 of the 6 pyrethroids (see Table 1). The filter paper was allowed to dry at room temperature for $1 \mathrm{~h}$ prior to installing the bees. A plastic lid (with holes for sugar and water bottles and for ventilation) was taped to the glass petri dish base. Bees were maintained for $24 \mathrm{~h}$ in a darkened controlled-environment chamber at $29{ }^{\circ} \mathrm{C}$ on $50 \%$ sucrose solution and water. After the 24:h exposure period 15 treated survivors and 15 untreated bees were used (when available) to compare their conditioning to odor. The entire procedure was repeated for each pyrethroid on 3 different days.

Our methods for restraining, odor training and testing the learning responses of honey bees were based on earlier work by Frings (1944), TAKeda (1961) and BitTerman et al. (1983). To facilitate proboscis-extension conditioning, individual bees were restrained in a bee holder with a small $(2 \times 0.7 \mathrm{~cm})$ cylindrical tube to hold the bee's body and reduce its mobility (Fig. 1). To prevent damage to the bees while fastening them into the bee holder, we put each individual bee into a vial which was covered with ice until the bee ceased movement. Each chilled bee was then quickly slipped into the tube on the holder and the stanchion device closed around its cervix. All chilled bees recovered immediately 


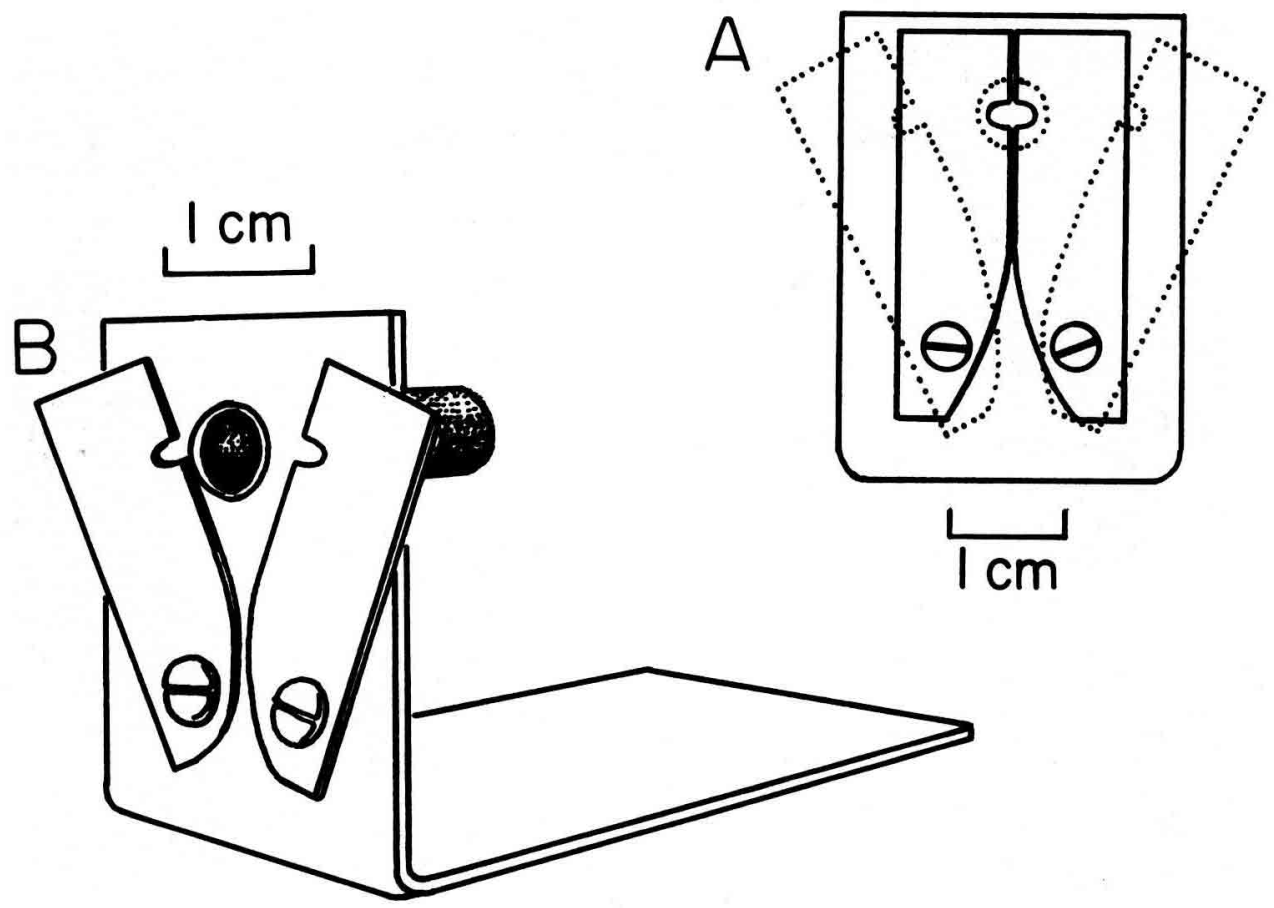

FIG. 1. - Stanchion-type bee holder showing the closing device and the tube to restrain a honey bee for conditioning and testing.

and were fed once after being placed in the bee holder. To insure that the bees were sufficiently hungry to give a positive response to sucrose solution they were then held for 3 hours without receiving additional nourishment.

Each bee was positioned singly in front of the exhaust duct and thyme-scented air from a closed plastic container was blown over its antennae (conditioned stimulus) using a small air-pump (Fig. 2). During the second half of a 6-sec scent-conditioning interval, the antennae were touched with a small pipet that had been dipped in a $30 \%$ sucrose solution (unconditioned stimulus, US). The odor stream was removed from the antennae after $6 \mathrm{sec}$ and the pipet was then touched briefly to the extended proboscis (compound-US). When proboscis extension was not induced by either the odor stream on the antennae or antennal or proboscis contact with the sugar solution, we attempted to free the proboscis in hopes that the bee would respond in subsequent training bouts. A bee unable to extend its proboscis in 3 training bouts was categorized as non-functional and was not included in our calculations. Between 90.5 and $100 \%$ of the bees that were placed in holders in the various treatment groups were classified as functional bees.

Each bee was tested and then conditioned with the combination of odor and sugar solution 8 times with inter-trial intervals of ca $15 \mathrm{~min}$. (Although 8 bouts of testing and conditioning were used with each bee, only 7 are mentioned in the results because no conditioning preceded the first bout of testing.) A bee that extended its proboscis during the first $3 \mathrm{sec}$ (when no antennal contact with sugar was in progress) was considered to have responded positively to odor training. When a bee extended its proboscis only during sugar solution contact with its antennae (second $3 \mathrm{sec}$ ), it was considered to have given a negative response (untrained). As mentioned previously, a bee unable to extend its proboscis in 


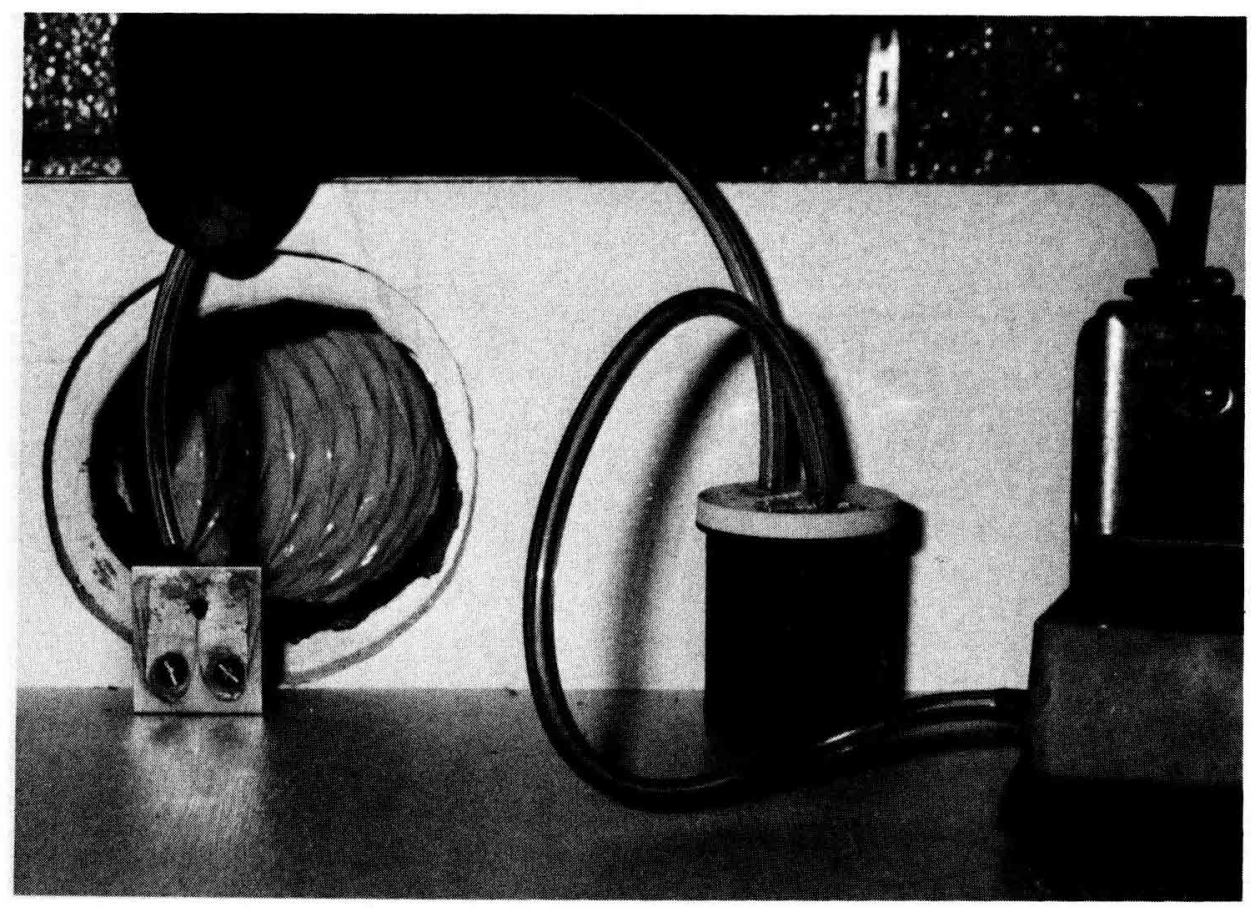

Fig. 2. - Application of the conditioned stimulus to a restrained honey bee positioned near the air exhaust duct.

any given training bout was counted as non-functional. A bee that extended its proboscis immediately after it had been positioned in front of the exiting air duct (position response), viz. before the training scent was blown over its antennae, was not considered to have shown either positive or negative responses for that particular training sequence and was discarded from further testing.

Data for percent positive responses were subjected to 6 analysis of variance (ANOVA) procedures as follows : one for pyrethroid-treated bees and another for control bees in training bouts 1-3, one for pyrethroid-treated bees and another for control bees in training bouts 4-7, and one for pyrethroid-treated bees and another for control bees in training bouts 1-7. Each of these ANOVA's having a significant sequence effect was tested by individual degrees of freedom (linear, quadratic, etc.) using orthogonal comparisons in regression (STEEL and TORRIE, 1980). Additional ANOVA's were done for each sequence of training bouts combining treated and control bees; the Student Newman Kuels (SNK) mean separation technique was used to determine the significance of response differences between bees treated with each pyrethroid and their respective control bees (SoKal and RoHLF, 1969).

\section{RESULTS}

Bees not exposed to a sublethal dose of any pyrethroid gave about $60 \%$ positive responses after a single training bout. This increased ca. $10 \%$ following each of the next 3 training bouts to achieve ca 70,80 and $90 \%$ positive 
responses after 2,3, and 4 training bouts, respectively (Table 1). Analysis of the proportion of control bees exhibiting positive responses after only 3 training bouts showed a significant linear relationship to sequence but a nonsignificant quadratic relationship (Table 2). Training bouts 4-7 resulted in no further increase in positive responses by control bees (non-significant sequence effect). Analysis of variance results for training bouts 1-7 produced a significant sequence effect that was both linear and quadratic. Control bees responded uniformly throughout all tests associated with the 6 pyrethroids (non-significant «compound » effect).

TABL. 1. - Percentage of honey bees responding positively to conditioned odor responses following training bouts one through seven - bees either survived an $L C_{50}$ dose of the indicated pyrethroid or were acetone-treated controls

\begin{tabular}{|c|c|c|c|c|c|c|c|c|c|}
\hline & \multirow{2}{*}{$\begin{array}{c}\mathrm{LC}_{50} \\
\text { Dosage } \\
\text { (mg / dish) }\end{array}$} & \multirow{2}{*}{$\begin{array}{l}\text { Total } 1 / \\
\text { \# bees }\end{array}$} & \multicolumn{7}{|c|}{ Training bout } \\
\hline & & & 1 & 2 & 3 & 4 & 5 & 6 & 7 \\
\hline Fluvalinate & 10.00 & 39 & 38.5 & 52.6 & $58.8 * 2 !$ & $62.2 *$ & 65.7 & 67.7 & 72.7 \\
\hline Fenvalerate & 1.00 & 34 & $26.7^{* *}$ & $41.2^{* *}$ & $53.1 *$ & $55.9^{* *}$ & 66.7 & $59.4^{*}$ & 69.7 \\
\hline Permethrin & 0.06 & 40 & 41.7 & $47.5^{*}$ & 65.8 & $59.5^{* *}$ & $61.1^{*}$ & $61.1^{*}$ & 67.7 \\
\hline Cypermethrin & 0.10 & 38 & 34.2 & $40.0^{*}$ & 52.8 & $58.3^{*}$ & 67.7 & $57.6^{*}$ & 62.9 \\
\hline Cyfluthrin & 0.10 & 36 & $02.9^{* *}$ & $25.0^{* *}$ & $33.0^{* *}$ & $53.1^{* *}$ & $60.0^{* *}$ & $59.4^{*}$ & 60.0 \\
\hline Flucythrinate & 1.00 & 37 & $24.2 *$ & $32.4^{* *}$ & $36.1^{* *}$ & $44.0^{* *}$ & $36.1^{* *}$ & $42.9^{* *}$ & $47.2 * *$ \\
\hline $\begin{array}{l}\text { Acetone controls } \\
\text { (mean) }\end{array}$ & - & 252 & 62.9 & 76.4 & 83.9 & 90.3 & 91.7 & 90.5 & 89.6 \\
\hline
\end{tabular}

$1 /$ Each daily test began with 15 pyrethroid-treated bees and 15 acetone-treated bees - viz. three days per pyrethroid.

2/ Statistical significance of treated bees versus their respective control as determined by Student Newman Kuels mean separation technique : ${ }^{* *}=\mathrm{P} \leqslant 0.05 ;^{*}=\mathrm{P} \leqslant 0.01$

TABL. 2. - Analysis of variance F-values and significance for responses of honey bee to odorconditioning tests after exposure to one of six pyrethroids in acetone or to acetone alone.

\begin{tabular}{l|c|c|c|c|c|c}
\hline & \multicolumn{3}{|c|}{ Control bees } & \multicolumn{3}{c}{ Treated bees } \\
\cline { 2 - 7 } Training bout & $1-3$ only & $4-7$ only & $1-7$ & $1-3$ only & $4-7$ only & $1-7$ \\
\hline Source of variation & & & & & & \\
Compound 1' & $2.4 \mathrm{~ns} 2^{\prime \prime}$ & $0.7 \mathrm{~ns}$ & $0.7 \mathrm{~ns}$ & $3.2^{*}$ & $2.6 \mathrm{~ns}$ & $5.1^{*}$ \\
Sequence & $24.5^{* *}$ & $0.7 \mathrm{~ns}$ & $37.2^{* *}$ & $49.0^{* *}$ & $3.1^{*}$ & $14.8^{* *}$ \\
Linear & $47.4^{* *}$ & - & $166.3^{* *}$ & $96.9^{* *}$ & $7.7^{*}$ & $75.5^{* *}$ \\
Quadratic & $1.2 \mathrm{~ns}$ & - & $59.9^{* *}$ & $0 \mathrm{~ns}^{*}$ & $0.4 \mathrm{~ns}$ & $7.4^{* *}$ \\
Comp. X Seq. & $0.6 \mathrm{~ns}$ & $1.2 \mathrm{~ns}$ & $1.0 \mathrm{~ns}$ & $3.7^{*}$ & $0.7 \mathrm{~ns}$ & $0.2^{\mathrm{ns}}$ \\
\hline \hline
\end{tabular}

$1 /$ Control bees were done at the same time as bees exposed to one of six pyrethroids.

$\underline{2} /$ Statistical significance of treatment effet : ${ }^{* *}=\mathrm{P} \leqslant 0.01,{ }^{*}=\mathrm{P} \leqslant 0.05$, ns $=\mathrm{P}>0.05$. 
Bees surviving exposure to a pyrethroid had means of only ca $30 \%$ positive responses after a single training bout, with a range of 3 to $42 \%$ (Table 1). Percent positive responses by treated bees showed a statistically significant effect for compounds when either training bouts 1-3 or training bouts 1-7 were tested, but not when training bouts 4-7 were tested (Table 2). The mean positive response by pyrethroid survivors (all 6 treatments) also increased by ca $10 \%$ after both the second and third training bouts to ca 40 and $50 \%$, respectively. Pyrethroid-treated bees increased their positive responses slightly after training bouts $4-7$, but reached a mean of only $63 \%$ after the seventh training bout. Thus, there was a significant sequence effect (linear only) on positive responses when training bouts 4-7 were statistically examined using ANOVA. The significant compound by sequence interaction for treated bees in training bouts 1-3 is a result of different learning responses slopes for cyfluthrin and flucythrinate than for the other 4 pyrethroids.

\section{DISCUSSION AND CONCLUSIONS}

Many scientists have attributed visitation suppression following the spraying of crop fields with pyrethroids to repellency of honey bees by these insecticides. There has been limited debate about the accuracy of this conclusion, although it is generally agreed that honey bees cease foraging for periods of a few hours to several days following the application of a pyrethroid insecticide to a crop, depending on the chemical applied and the rate of application (ATKINS et al., 1978). HAYNES and BAKER (1985) showed that pink bollworm adults were unable to communicate normally via olfactory means after surviving a sublethal dose of permethrin. They found that both female mate-calling and male mate-finding were disrupted. Haynes (pers. comm.) reported that fenvalerate was less toxic to PBW than was permethrin, but it was more disruptive of mating behavior than was permethrin. We should not be surprised to learn that a conditioned response to odor by the honey bee is also affected.

Our conditioning tests clearly showed that honey bees surviving the $\mathrm{LC}_{50}$ exposure to all pyrethroid insecticides tested had a reduced initial learning response and that the degree of learning achieved after 7 training bouts was also reduced. Honey bees exposed only to acetone-treated filter paper (controls) had learning responses following training bouts $1-3$ of ca 60 to $80 \%$, respectively, but then reached an asymptote at ca $90 \%$ positive responses following training bout 4 . By contrast, bees exposed to pyrethroids had learning responses following training bouts $1-3$ of ca 30 to $50 \%$, respectively, and did not reach an asymptotic relationship within our test period. 
Three pyrethroids were significantly different from others in these tests. Fluvalinate, having a lower toxicity to the honey bee, was applied at a relatively high rate and yet had the least impact of all pyrethroids tested on honey bee learning. Cyfluthrin was unique in that after the first 3 training bouts it was the only pyrethroid to be significantly different from any of the others, while flucythrinate tended to suppress conditioned responses more after the later training bouts. Following training bout 4, all 6 pyrethroids significantly reduced the level of responses by honey bees below that of the associated control bees (SNK test) ; but, following training bout 7 only flucythrinate had a statistically significant effect. In fact, flucythrinate reduced the number of positive responses significantly in every sequence of training bouts after the initial exposure to odor.

Comparisons between the pyrethroids tested must be made with caution owing to their widely varying toxicity (and consequent dosage in these tests) and because our procedures required 3 days to complete the experimentation needed to test each pyrethroid. Using the SNK to make comparison between pyrethroids within each sequence of training bouts we found cyfluthrin to be significantly different from all other pyrethroids after training bout 1 , different only from fluvalinate and permethrin after training bout 2 , and different from permethrin alone after training bout 3 . On the other hand, flucythrinate was significantly different from all other pyrethroids only after training bout 6 .

We propose that the observed inhibition of foraging activity by honey bees following treatment of a crop with one of the pyrethroid insecticides results from a sublethal toxic dysfunction. We do not know whether the toxicant has the peripheral or central nervous system (CNS) as its prime target. Impaired response to the scent stimulus and/or sugar water may be the result of peripheral receptor, interneuron, or site specific CNS blockage. The mode of action of pyrethroids on insects is unknown except for general agreement that the symptoms indicate an attack on the nervous system (Miller and Salgado, 1985). Further laboratory and field research is needed to determine the fate and subsequent behavior of honey bees that survive exposure to pyrethroids.

Received for publication in August 1986 Accepted for publication in January 1987.

\section{ACKNOWLEDGEMENTS}

We thank J. Martin, J. Reith and H. Karpeles for assistance with handling the bees, L. Gasca for making the bee holders, B. SAGER and C. BRAmLeY for typing the manuscript, M. BuchmanN for drawing Fig. 1, Dr. H. C. Brandes and Dr. K. Haynes for helpful suggestions, and Dr. G. Richardson for advice on statistical procedures. This study was done in partial fulfillment of the requirements for the M.S. degree in Entomology from the University of Arizona by the senior author. Research funded in part by Western Region Pesticides Impact Assessment Program Agreement No. CE-15-84. 


\section{RÉSUMÉ \\ DIMINUTION D'UNE RÉPONSE CONDITIONNÉE CLASSIQUE DE L'ABEILLE (APIS MELLIFICA L.) PAR DES DOSES SUBLÉTALES D'INSECTICIDES PYRÉTHRINOÏDES DE SYNTHESE}

Lors d'études préliminaires (publiées sćparément), les auteurs ont déterminé pour l'abeille les concentrations $\mathrm{CL}_{50}$ de contact des six pyréthrinoïdes de synthèse suivants : cyperméthrine, cyfluthrine, fenvalérate, flucythrinate, fluvalinate et perméthrine. Des butineuses capturées à leur sortie de la ruchc furent enfermées pendant 24 heures dans une boîte de pétri avec du papier filtre préalablement imbibé d'acétone (témoin) ou de chacun des six pyréthrinoïdes dissout dans l'acétone à la concentration $\mathrm{CL}_{50}$. Lors de tests journaliers, les réponses au conditionnement olfactif des abeilles survivantes à chacun des pyréthrinoïdes furent comparées à celles des abeilles soumises au traitement témoin.

Les abeilles furent placées dans des enceintes individuelles construites spécialement (Fig. 1) et privées de nourriture trois heures avant le début du conditionnement. Lors de ces tests, chaque abeille était placée face à une bouche d'air dans son enceintc. Un courant d'air parfumé au thym était envoyé sur les antennes de l'abeille pendant six secondes (stimulus conditionnel). Durant les trois dernières secondes, une solution sucrée (stimulus non conditionnel) contenant $30 \%$ de saccharose était mise en contact d'abord avec les antennes, puis, après la période de 6 secondes, avec le proboscis étendu (Fig. 2). Une réponse positive correspondait à une extension du proboscis lors des trois premières sccondes. Chaque abeille fut soumise à une série de huit essais similaires séparés par des intervalles d'environ 15 minutes. Bien que le but fût de comparer 15 abeilles témoins et 15 abeilles traitées (survivantes exposées à un pyréthrinoïde) pour chaque pyréthrinoïde durant trois jours d'essais, cela n'a pas toujours été possible à cause de la mortalité, des manipulations ou de l'absence de réponses de certaines butincuses.

Les abeilles témoins répondirent positivement de façon pratiquement uniforme avec un taux de $60 \%$ après le premicr essai, ce taux s'élevant rapidement à $90 \%$ de réponses positives après quatrc essais (Tabl. 1). Les abeilles traitées répondirent de façon variable (en fonction du pyréthrinoïde), mais avec un taux de réponses positives de l'ordre de $30 \%$ (de 3 à $42 \%$ ) après un essai, $50-60 \%$ après 4 essais, et 60-70\% ensuite. Le fluvinate affecta le moins les réponses au conditionnement alors que le flucythrinate et la cyfluthrine perturbèrent le plus celles-ci. Après le quatrième essai, les abeilles exposées aux six pyréthrinoïdes ne présentèrent pas de réduction statistiquement significative de leur taux de réponses positives comparé à celui des abeilles témoins. Après le septième essai, seules les abeilles exposées au flucythrinate avaient un taux de réponses au conditionnement olfactif significativement inféricur à celui des abeilles témoins.

Ces tests de conditionnement mettent clairement en évidence que les insecticides pyréthrinoïdes ralentissent le taux et réduisent le degré d'apprentissage des butineuses survivantes (Tabl. 2). Suite à des applications de pyréthrinoïdes, on a rapporté des interruptions de butinage par les abeilles de quelques heures à quelques jours selon le produit et la dose utilisés. Cette étude suggère que la baisse de butinage sur les cultures traitées avec un pyréthrinoïde pourrait résulter d'un affaiblissement de la capacité d'apprentissage olfactif. D'autres recherches basées sur des études en enceintes pourraient élucider la façon complexe dont cette inhibition du butinage se produit.

\section{ZUSAMMENFASSUNG}

\section{GERINGERE REAKTION VON HONIGBIENEN (APIS MELLIFERA L.) BEI KLASSISCHEN KONDITIONIERUNGEN NACH BEHANDLUNG MIT SUBLETALEN MENGEN SYNTHETISCHER INSEKTIZIDE (PYRETHROIDE)}

Zur Vorbereitung der dargestellten Experimente bestimmten dic Autoren LD $_{50}$ Werte (separate Publikation) von 5 verschiedenen synthetischen Pyrethroiden (Cypermethrin, Cyfluthrin, Fenvalerate, 
Flucythrinate, Fluvalinate und Permethrin). Ausfliegende Sammlerinnen wurden gefangen und 24 Stunden in einer Petrischale auf Filterpapier gehalten, das mit der zuvor bestimmten LD $_{50}$ Dosis einer der sechs Pyrethroide benetzt war. Lösungsmittel für dic Pyrethroide war Aceton. Eine Kontrollgruppe erhielt Aceton-getränktes Filterpapier. Wir verglichen die Reaktion von überlebenden Bienen der behandelten Gruppen in eintägigen Lerntests mit der Reaktion der Kontrollgruppen.

Einzelbienen wurden in einem speziell konstruicrten Bienenhalter befestigt (Abb. 1) und drei Stunden vor dem Beginn der Experimente ohne Futter gehalten. Die so befestigten Bienen wurden dann während der Lerntests vor einen Abzug gesetzt und die Antennen 6 Sekunden mit Thymianduft angeblasen (konditionierter Stimulus). Während des letzten drei Sekunden wurden zuerst die Antennen mit einer $30 \%$ Rohrzuckerlösung berührt anschliessend der ausgestreckte Rüssel (unkonditionierter Stimulus). Der Lernerfolg der Bienen zeigte sich durch positive Reaktion (Rüssel-ausstrecken) während der crsten drei Sekunden (Abb. 2). Jede Biene wurde in acht Lernakten konditioniert und getestet. Die Zeitspanne zwischen den Tests betrug 15 Minuten. Wir wollten pro Pyrethroid an 3 verschiedenen Tagen jeweils 15 Testbienen (Überlebende der Pyrethroidbehandlung) mit 15 Kontrollbienen vergleichen, an einigen Tagen konnten wir nicht alle Bienen auswerten, da Bienen entkamen oder nicht funktionsfähig waren.

Die Kontrollbienen reagierten mit nur geringen Unterschicden nach einem Lernakt zu $60 \%$ auf den konditionierten Reiz und erreichten nach 4 Lernakten ein Lernniveau von $90 \%$ (Tabelle 1). Die mit Inscktiziden behandelten Bienen reagierten je nach Pyrethroid unterschicdlich ; sie zeigten ungefähr $30 \%$ positive Reaktion nach cinem Lernakt (dic Reaktionen lagen zwischen 3 und $42 \%$ ), 50-60\% positive Reaktion nach vier Lernakten, 60-70\% positive Reaktion in weiteren Lernakten. Das Duftlernen war am geringsten durch Fluvalinate beeinflusst, die grössten Effekte zeigten sich bei Flucythrinate und Cyfluthrin (Tabelle 1). Beim vierten Lernakt zeigten alle sechs mit Pyrethroid behandelten Gruppen signifikant geringere - positive - Reaktion als die Kontrollgruppen. Beim sicbenten Lernakt war nur dic Lernrate der mit Flucythrinate behandelten Bienen signifikant niedriger.

Dic Konditionicrungstests zeigen deutlich, dass Pyrethroide die Lernrate und das Lernniveau von überlebenden Sammlerinnen reduzicren (Tabelle 2). Bei Honigbienen wird berichtet, dass, abhängig von der Pyrethroid-Behandlung und Dosicrung, zwischen Stunden und mehreren Tagen keine Sammeltätigkeit erfolgt. Diese Arbeit legt nahe, dass geringere Sammeltätigkeit auf Pyrethroid-behandelten Pflanzen durch eine Verschlechterung der olfaktorischen Lernfähigkeit bedingt ist. Weitere Untersuchungen sollen die komplexen Zusammenhänge klären, die eine hemmende Wirkung auf die Sammlerinnen verursachen.

\section{REFERENCES}

AткіnS E.L., 1981. - Repcllents reduce insecticidal kills of honcybees. In : Proc. 28th Intern. Cong. Apiculture, Apimondia Publ. House, Bucharest, Romania, 305-310.

Atkins E.L., Kellum D., AtKins K.W., 1978. - Integrated pest management strategies for protecting honey bees from pesticides. Amer. Bee J., 118, 542-543, 547-548.

Atkins E.L., Kelium D., Aткіns K.W., 1981. - Reducing pesticide hazards to honey bees : mortality prediction techniques and integrated management strategies. Univ. of Calif. Leaflet No. 2883, 23 p.

Bitterman M.E., Menzel R., Fietz A., Schafer S., 1983. - Classical conditioning of proboscis extension in honcybecs (Apis mellifera). J. Comp. Psychol., 92, 107-119.

Brandes C., 1984. - Tanztempo. Zuckerverbrauch, Lauf-, Fluggeschwindigkcit und Flügclschlagfrequenz von Apis mellifera carnica nach subletaler Parathionvergiftung. Zool. Jb. Physiol., 88, 345-359.

Cox R.L., WILson W.T., 1984. - Effects of permethrin on the behavior of individually tagged honey bees, Apis mellifera L. (Hymenoptera : Apidae). Environ. Entomol., 13, 375-378.

Floyd J.P., Crowder L.A., 1981. - Sublethal effects of permethrin on pheromone response and mating of male pink bollworm moths. J. Econ. Entomol., 74, 634-638.

Frings H., 1944. - The loci of olfactory end-organs in the honey-bec, Apis mellifera Linn. J. exp. Zool., 97, 123-134. 
GARY N.E., 1967. - A method for evaluating honey bee flight activity at the hive entrance. J. Econ. Entomol, 60, 102-105.

Gerig L., 1979. - Bienengiftigkeit der synthetischen Pyrethrine. Schweizerische Bienen-Zeitung., 102, 228-236.

Haynes K.F., BaKer T.C., 1985. - Sublethal effects of permethrin on the chemical communication system of the pink bollworm moth, Pectinophora gossypiella. Arch. Insect Biochem. Physiol., 2, 283293.

KaIssling K.E., 1980. - Action of chemicals, including $(+)$ trans-Permethrin and DDT, on insect olfactory receptors. In: Insect Neurobiology and Pesticide Action (Neurotox 79), Proc. Chem. Industry, Univ. of York, England. Soc. Chem. Industry, London, 351-358.

LinN C.E. Jr., Roelors W.L., 1984. - Sublethal effects of neuroactive compounds on pheromone response thresholds in male oriental fruit moths. Arch. Insect Biochem. Physiol, 1, 331-334.

Miller T.A., Salgado V.L., 1985. - The mode of action of pyrethroid insecticides. In : J.P. Leahey, ed. The pyrethroid insecticides. Taylor and Francis, London, 43-97.

Moffett J.O., Stoner A., Ahring R.M., 1982. - Effect of fenvalerate applications on honey bees in flowering alfalfa. Southwest. Entomol., 7, 111-116.

Pike K.S., Mayer D.F., Glazer M., Kious C., 1982. - Effects of permethrin mortality and foraging behavior of honey bees in sweet corn. Environ. Entomol., 11, 951-953.

Schricker B., 1974 a. - Einfluss subletaler Dosen von Parathion (E 605) auf die Entfernungsweisung bei der Honigbiene. Apidologie, 5, 149-175.

Schricker B., 1974 b. - Der Einfluss subletaler Dosen von Parathion (E 605) auf das Zeitgedächtnis der Honigbiene, Apidologie, 5, 385-398.

Schricker B., STEPHeN W.P., 1970. - The effect of sublethal doses of parathion on honeybee behaviour. I. Oral administration and the communication dance. J. Apic. Res., 9, 141-153.

Smart L.E., Stevenson J.H., 1982. - Laboratory estimation of toxicity of pyrethroid insecticides to honeybees: Relevance to hazard in the field. Bee World, 63, 150-152.

SoKal R.R., Rohlf F.J., 1969. - Biometry. 1st ed. W.H. Freeman Co., San Francisco, 776 p.

Steel R.G.D., Torrie J.H., 1980. - Principles and Procedures of Statistics (2nd Ed.). McGraw-Hill, N.Y., 633 p.

Stevenson J.H., Needham P.H., Walker J., 1977. - Poisoning of honeybees by pesticides : Investigations of the changing pattern in Britain over 20 years. Rothamsted Exp. Stn. Report for 1977, Part 2, $55-72$.

TAKEDA K., 1961. - Classical conditioned response in the honeybee. J. Insect Physiol., 6, 168-179. 